Z. klin. Chem. u. klin. Biochem.

9. Jg., S. 415-418, September 1971

\title{
Rapid Determination of Urinary Total Porphyrins by Ion Exchange Chromatography
}

\author{
By M. Doss and A. Schmidt \\ Clinical Biochemistry Division, Hygiene Institute of the Pbilipps University Marburg/Labn
}

(Eingegangen am 18. Juni 1971)

\begin{abstract}
Total urinary porphyrins were eluted from a commercially available anion exchange chromatographic column with hydrochloric acid and determined spectrophotometrically. For $1 \mathrm{ml}$ samples the optimum concentration range for measurement was found to lie between 0.1 and $1.5 \mathrm{mg}$ of total porphyrin/l urine. Assay of a single sample takes $12 \mathrm{~min}$. The specificity (measurement at three wave lengths), sensitivity $(20 \mu \mathrm{g} / \mathrm{l}$ ), and precision (variability coefficient $8 \%$ ) are sufficient to provide rapid information about total porphyrins.

Normal values were determined from findings on healthy test persons: $55 \pm 33 \mu \mathrm{g} / \mathrm{l}(\overline{\mathrm{x}} \pm \mathrm{s})$. For 24 patients with secondary porphyrinuria and hepatic porphyrias, assay of total prophyrins by ion exchange chromatography was compared to analysis using thin-layer chromatography; similar results were usually obtained with both methods, but concentration differences of up to $30 \%$ were also found.
\end{abstract}

Die Gesamtporphyrine des Urins wurden aus einer kommerziell verfügbaren Anionenaustauschchromatographiesäule mit Salzsäure eluiert und spektrophotometrisch bestimmt. Bei einem Probenvolumen von $1 \mathrm{ml}$ ergab sich ein optimaler Meßbereich für Konzentrationen von 0,1 bis $1,5 \mathrm{mg}$ Gesamtporphyrine/1 Urin. Die Analysenzeit beträgt $12 \mathrm{Min}$. für eine Probe. Spezifität (Messung bei drei Wellenlängen), Empfindlichkeit $(20 \mu \mathrm{g} / \mathrm{l})$ und Präzision (Variabilitätskoeffizient $8 \%$ ) sind für eine schnelle Information über Gesamtporphyrine ausreichend.

Normalwerte wurden in einer Stichprobe von 95 gesunden Probanden bestimmt: $55 \pm 33 \mu \mathrm{g} / 1(\overline{\mathrm{x}} \pm \mathrm{s})$. Bei 24 Patienten mit sekundären Porphyrinurien und hepatischen Porphyrien wurden die Gesamtporphyrine nach Ionenaustauschchromatographie mit dünnschichtchromatographischen Bestimmungen verglichen; neben Übereinstimmungen der Resultate fanden sich Konzentrationsdifferenzen bis zu $30 \%$.

Determination of total urinary porphyrins as copper chelates has proved in practice to be too time consuming for use in the clinical chemical routine laboratory (1). Although modifications of this method involving conversion of urinary porphyrins into zinc chelates (2) and centrifugation of the talcum adsorbate or assay of porphyrin methyl esters after rapid esterification (3) in methanol-sulfuric acid were considerable improvements (4), we prefer for the estimation of total porphyrins the procedure described as a screening test by CASTROw and coworkers (5), which takes advantage of commercially available, ready-made columns. In principle the method involves rough separation of the porphyrin fraction by ion exchange chromatography: The urine is filtered directly over an anion exchange resin, onto which the porphyrins are adsorbed and then eluted with hydrochloric acid.

In view of the genuine lack of an adequate quick method for the assay of total porphyrins in urine, we decided to determine the feasibility of rapid quantitative analysis of total urinary porphyrins, employing disposable ion exchange chromatographic resins. Our purpose was to develop the method so that it would be particularly well suited for clearly detecting the slight to moderate increases in porphyrin excretion such as are found in clinically occult disturbances of porphyrin synthesis.

\section{Procedures}

Subjects

A series of clinically healthy test persons consisting of the staff of the Hygiene Institute and students of the University in Marburg was studied. Each age group $(16-25,26-35,36-\ldots 65$ years) contained at least 14 persons. In addition, patients with secondary porphyrinuria in fatty liver and lead intoxication were examined, as well as patients with hepatic porphyrias such as acute intermittent porphyria, hereditary coproporphyria, chronic hepatic porphyria without clinical symptoms, and porphyria cutanea tarda.

Collection of urine samples

The studies were based on urine samples collected at random during the day and shielded from light. The $\mathrm{pH}$ was adjusted to $5-7$, and the urine stored at $-20^{\circ}$ until analyzed.

\section{Reagents}

Disposable ion exchange columns were obtained from Bio-Rad Laboratories ("Porphyrin Detection Columns" with wash solution $3 \mathrm{~N} \mathrm{HCl}$, Cat. No. 94002), Munich. The column is charged with the anion exchange resin AG $1-\mathrm{X} 8,50-100$ mesh $\left(\mathrm{Cl}^{-}\right)$. They were stored at about $4^{\circ}$.

Hydrochloric acid $3 \mathrm{~N}$.

Equipment and instruments

Test tubes $16 \times 160 \mathrm{~mm}$ (Fiolax No. 2771, Schott No. 2611021). Recording spectrophotometer.

Reference compounds

Uro- and coproporphyrin (III and I) from the urine of patients with porphyria cutanea tarda were isolated as methyl esters in a highly purified form by thin-layer chromatography (3). Samples 
of about $1-5 \mu \mathrm{g}$ were hydrolyzed with $25 \%$ (w/v) $\mathrm{HCl}$ for 48 hours at room temperature, then dried in a vacuum over $\mathrm{NaOH}$. The same procedure was used to convert coproporphyrin I methyl ester (Calbiochem) to its free acid form.

\section{Ion exchange chromatography}

Place the column on a test tube and wash the resin in the lower part of the column with about $8 \mathrm{ml}$ of distilled water (仓 full reservoir); all the distilled water should be allowed to run through. Pipette $1 \mathrm{ml}$ of urine along the wall of the column directly above the resin and elute interfering material with $8 \mathrm{ml}$ of distilled water. Permit liquid to pass through, then place column on a second test tube. Elute porphyrins twice with two $\mathrm{ml} 3 \mathrm{~N} \mathrm{HCl}$ each time, allowing complete passage of the first two $\mathrm{ml}$ before starting with the second and final portion.

\section{Absorption spectrophotometry}

The Soret ( $\mathrm{S}$ ) maximum of the porphyrins was measured. Absorption by a $4 \mathrm{ml}$ sample of a $3 \mathrm{~N} \mathrm{HCl}$ solution containing the porphyrins is registered in a double-beam spectrophotometer between 430 and $380 \mathrm{~nm}$, path length $2 \mathrm{~cm}$, using distilled water as the reference solution (Fig. 1).

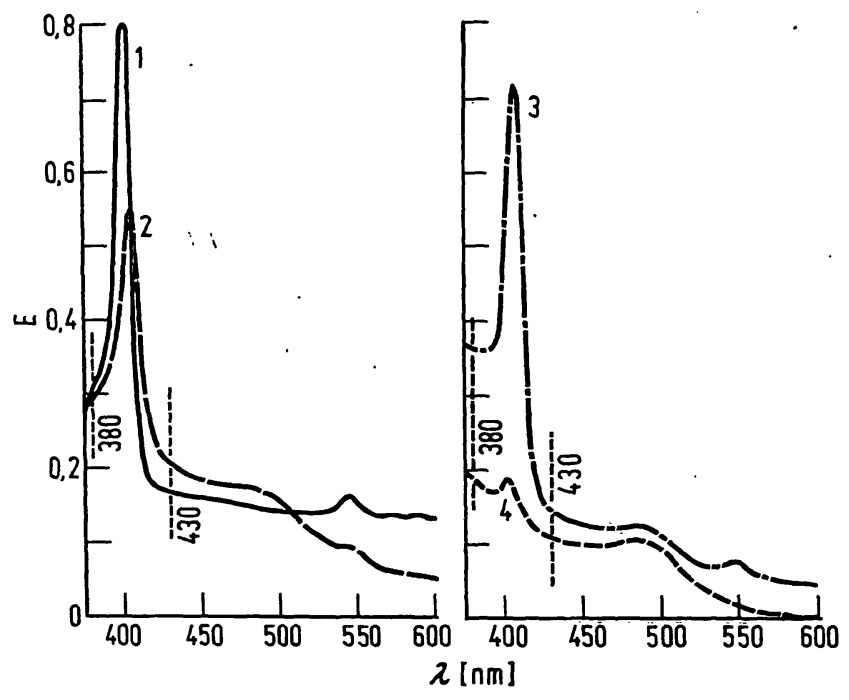

Fig. 1

Spectra of total urinary porphyrins (TUP) after elution from anion exchange resin $1 \times-8$ with $3 \mathrm{~N}$ hydrochloric acid ("porphyrin column test"): 1 Reference compound coproporphyrin III in $3 \mathrm{~N} \mathrm{HCl} \mathrm{(1} \mathrm{mg/l),}$ 2 TUP in case 23 : chronic hepatic porphyria $(483 \mu \mathrm{g} / 1)$, 3 TUP in case 15: acute intermittent porphyria $(614 \mu \mathrm{g} / 1)$, and 4 TUP from a $4 \mathrm{ml}$ of $\mathrm{HCl}$. Path length of the cuvettes $2 \mathrm{~cm}$. Spectrophotometer Beckman DB-G

\section{Calculations}

$$
E_{S \text { corr. }}=\frac{2 E_{S}-\left(E_{430}+E_{380}\right)}{k}
$$

Correctional factor $\mathrm{k}=1.8$

$$
\text { Total porphyrins }(\mu \mathrm{g} / \mathrm{ml})=\mathrm{E}_{\mathrm{S} \mathrm{corr.}}^{2 \mathrm{~cm}} \cdot 2.6
$$

Derivation of formula III:

Millimolar extinction coefficients of uro- and coproporphyrin in 3N $\mathrm{HCl}$ :

uroporphyrin 547;

coproporphyrin 486.

The factor $\mathrm{k}$ used in correcting the extinction values for the free porphyrin acids in samples of biological origin (cf. 6) was determined on the basis of the absorption of the reference compounds in the Soret band:

$$
\begin{gathered}
k=\frac{2 E_{S}-\left(E_{430}+E_{380}\right)}{E_{S}} \\
k_{\text {uroporphyrin }}=1.78
\end{gathered}
$$

$$
k_{\text {coproporphyrin }}=1.80
$$

By transposing IV we obtain $E_{S}$ corr. as in I.

Taking the usual ratio of uro- to coproporphyrin in normal urine to be about 4:1 (7), a mean molecular weight of 691 and a mean millimolar extinction coefficient of 498 were determined for uroplus coproporphyrin. These values are used in the following calculation of total porphyrins:

Total porphyrins $(\mu \mathrm{g} / \mathrm{ml}$ urine $)=$

$$
\frac{\mathrm{E}_{\mathrm{S}} \text { corr. } \cdot 691 \cdot \mathrm{HCl} \text { volume }(\mathrm{ml})}{498 \cdot \mathrm{d}(\mathrm{cm}) \cdot \text { urine sample volume }(\mathrm{ml})}
$$

If $\mathrm{d}=2 \mathrm{~cm}$, we arrive at the simplified formula III from equation VII

\section{Sensitivity}

The amount corresponding to the doubled standard deviation of the individual determinations (2s) is about $20 \mu \mathrm{g} / \mathrm{l}$. However, practice has shown that amounts as small as $5 \mu \mathrm{g} / \mathrm{l}$ can be distinguished from zero in $4 \mathrm{ml}$ urine samples.

\section{Accuracy}

Of $10 \mu \mathrm{g}$ of coproporphyrin added to $10 \mathrm{ml}$ of normal urine, about $75 \%$ was recovered in each of eight separate samples.

\section{Precision}

Variability coefficients for two series $(n=8$ each) were 6 and $12 \%$ $(\overline{\mathrm{x}}=126 \mu \mathrm{g} / \mathrm{l})$.

\section{Interfering factors}

The extinction of the eluted porphyrins in $3 \mathrm{~N} \mathrm{HCl}$ decreased by about $25 \%$ in three hours in neon light at room temperature. In order to prevent such diminution, measurements should be made immediately following elution.

The corrected extinction value for normal urine with a low porphyrin content can be practically zero if the eluate contains substances whose absorption increases continuously between 440 and $370 \mathrm{~nm}$ and at $380 \mathrm{~nm}$ substantially exceeds that of the Soret band of the porphyrins.

\section{Results}

Total porphyrins in urine were assayed quantitatively with the aid of commercially prepared anion exchange columns. For $1 \mathrm{ml}$ samples the optimum concentration range for measurement was found to lie between 0.1 and $1.5 \mathrm{mg}$ of total porphyrin/l urine. A single analysis took 12 minutes. Typical spectra are shown in figure 1 ; the measure of concentration was the intensity of the absorption in the Soret region. The absorption maximum for the total porphyrin fraction in $3 \mathrm{~N}$ hydrochloric acid after ion exchange chromatography was found as a rule between 402 and $404 \mathrm{~nm}$. This absorption maximum is specific for porphyrins under the conditions prevailing here. Nevertheless, in urine containing large amounts of pigment other substances are also eluted from the resin AG $1-\mathrm{X} 8$ with hydrochloric acid. Since some emit a green fluorescence under UV light $(366 \mathrm{~nm})$, the Soret maximum cannot be relied upon as the sole parameter unless it is corrected (cf. 6).

Bilirubin in amounts up to $10 \mu \mathrm{g}$ and hemin chloride in amounts up to $100 \mu \mathrm{g}$ applied to the column could not be eluted under the conditions used for porphyrins. However, porphobilinogen in urine samples from patients with acute intermittent porphyria excreting up to $80 \mathrm{mg} / \mathrm{l}$ was detected with EHRLICH's reagent in 
the hydrochloric acid porphyrin eluate. The color complex was spectrophotometrically identical to that of pure porphobilinogen. Porphobilinogen in the porphyrin eluate did not interfere with porphyrin absorption, because this monopyrrol exhibits no absorption between 450 and $360 \mathrm{~nm}$. Therefore, the simultaneous elution of porphobilinogen does not restrict the specificity of the method for porphyrin estimation.

In $2 \%$ of the determinations of normal urine it was not possible to obtain a quantitative result, since the corrected extinction was zero due to relatively high background absorption by the eluate; nevertheless, a porphyrin absorption peak in the Soret region was clearly evident, and can be considered qualitative proof of the presence of porphyrin. The eluates of such samples were light pink to pale brown in color. Comparative studies (3) have shown that the porphyrin concentrations of these urine samples usually lie near the lower limit of normal.

Examination of a urine sample from a patient with porphyria cutanea tarda, which contained no interfering substances, revealed a linear relationship to the concentration for both the actually measured optical density at the Soret maximum and the corrected extinction, whereby the two values nearly coincided. A linear curve of the unadjusted extinctions in the Soret band corresponding to the actual concentrations was observed only for urine with an extremely high porphyrin content. For this reason the corrected extinction values were taken as the basis for calculation of the concentrations in unknown test samples. Correction is indispensible for determinations involving excretion of porphyrin to about $1 \mathrm{mg} / \mathrm{l}$, as well as within the normal range.
Thin-layer chromatographic studies have revealed that normal urine contains less than $0.1 \mathrm{mg}$ of porphyrin per liter (7). Since these concentrations lie within the lower range of the column method, $4 \mathrm{ml}$ of urine was chromatographed for determination of the normal values. Under these conditions the optimum range of measurement was found to lie between 4 and $200 \mu \mathrm{g} / 1$; the concentration curve was linear up to $500 \mu \mathrm{g} / 1$. The normal values determined for the group of healthy test persons are given in table 1. They conformed to a normal distribution curve. On the basis of comparison with a urine sample which was included in each of the eight series as a standard $(124 \pm 14 \mu \mathrm{g} / \mathrm{l}, \overline{\mathrm{x}} \pm \mathrm{s})$, a variability coefficient of $11 \%$ was found.

In table 2 data from the column assays are compared to results of thin-layer chromatographic analyses. The latter were obtained by taking the sum of the individual components after their separation in thin-layer chromatography and subsequent spectrophotometric measurement (3). In addition to the healthy persons, the study included patients with secondary coproporphyrinuria in fatty liver and chronic lead poisoning (7), with acute intermittent porphyria and hereditary coproporphyria in the latent phase (8), with chronic hepatic porphyria $(8,9)$, and with porphyria cutanea tarda (7-9). Considering the completely different principles of the

Table 1

Normal values of urinary total porphyrins in anion exchange chromatography

\begin{tabular}{ccc}
\hline & $\mathrm{n}$ & $\begin{array}{c}\text { Porphyrins } \\
(\mu \mathrm{g} / \mathrm{l}, \overline{\mathrm{x}} \pm \mathrm{s})\end{array}$ \\
\hline Persons & 95 & $55 \pm 33$ \\
$\mathrm{o}^{\circ}$ & 48 & $57 \pm 33$ \\
(⿻) & 47 & $47 \pm 33$ \\
\hline
\end{tabular}

Table 2

Comparison of results obtained by anion exchange chromatography (AEC-AS) and by thin-layer chromatography, both used in conjunction with absorption spectrophotometry (TLC-AS)

\begin{tabular}{|c|c|c|c|c|c|c|}
\hline \multirow[t]{2}{*}{ Groups studied } & \multirow[b]{2}{*}{ Number } & \multicolumn{2}{|c|}{ Subjects } & \multirow[b]{2}{*}{ Age } & \multicolumn{2}{|c|}{$\begin{array}{c}\text { Porphyrins } \\
(\mu g / l)\end{array}$} \\
\hline & & Initials & Sex & & in $A E C-A S$ & in TLC-AS \\
\hline , & $\begin{array}{l}1 \\
2 \\
3 \\
4 \\
5 \\
6 \\
7\end{array}$ & $\begin{array}{l}\text { E. S. } \\
\text { E. M. } \\
\text { R. V. } \\
\text { M. N. } \\
\text { S. Q. } \\
\text { G. S. } \\
\text { H. B. }\end{array}$ & $\begin{array}{l}\text { o } \\
\text { ơ } \\
\sigma^{\prime \prime} \\
\sigma^{\prime \prime} \\
\sigma^{\prime \prime} \\
\sigma^{\prime \prime} \\
\sigma^{\prime \prime}\end{array}$ & $\begin{array}{l}20 \\
30 \\
21 \\
22 \\
34 \\
35 \\
58\end{array}$ & $\begin{array}{r}47 \\
19 \\
107 \\
39 \\
80 \\
39 \\
69\end{array}$ & $\begin{array}{l}49 \\
32 \\
31 \\
50 \\
88 \\
30 \\
74\end{array}$ \\
\hline Alcoholic fatty liver & $\begin{array}{l}10 \\
11\end{array}$ & $\begin{array}{l}\text { K. W. } \\
\text { H. F. }\end{array}$ & $\sigma^{\prime \prime}$ & 46 & $\begin{array}{l}193 \\
278\end{array}$ & $\begin{array}{l}208 \\
254\end{array}$ \\
\hline Lead poisoning & 12 & G. L. & $\sigma^{\prime}$ & 31 & 668 & 565 \\
\hline $\begin{array}{l}\text { Acute intermittent porphyria (in remission) } \\
\text { Hereditary coproporphyria (in remission) }\end{array}$ & $\begin{array}{l}13 \\
14 \\
15 \\
16 \\
17\end{array}$ & $\begin{array}{l}\text { P. P. } \\
\text { H. B. } \\
\text { D. M. } \\
\text { A. B. } \\
\text { A. S. }\end{array}$ & 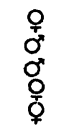 & $\begin{array}{l}45 \\
49 \\
24 \\
33 \\
62\end{array}$ & $\begin{array}{l}835 \\
525 \\
681 \\
222 \\
783\end{array}$ & $\begin{array}{l}975 \\
755 \\
560 \\
153 \\
705\end{array}$ \\
\hline $\begin{array}{l}\text { Chronic hepatic porphyria (without clinical symptoms) } \\
\text { Type A }\end{array}$ & $\begin{array}{l}18 \\
19 \\
20 \\
21\end{array}$ & $\begin{array}{l}\text { W. E. } \\
\text { A. H. } \\
\text { E. B. } \\
\text { W. W. }\end{array}$ & $\begin{array}{l}O^{\prime} \\
O^{\prime} \\
\sigma^{\prime \prime} \\
\sigma^{\prime \prime}\end{array}$ & $\begin{array}{l}58 \\
52 \\
46 \\
47\end{array}$ & $\begin{array}{l}130 \\
350 \\
229 \\
243\end{array}$ & $\begin{array}{l}166 \\
349 \\
366 \\
367\end{array}$ \\
\hline Type B & $\begin{array}{l}22 \\
\mathbf{2 3}\end{array}$ & $\begin{array}{l}\text { A. G. } \\
\text { M. R. }\end{array}$ & $O_{0}^{\prime}$ & $\begin{array}{l}57 \\
60\end{array}$ & $\begin{array}{l}123 \\
444\end{array}$ & $\begin{array}{l}183 \\
500\end{array}$ \\
\hline Type C & $\begin{array}{l}24 \\
25\end{array}$ & $\begin{array}{l}\text { R. C. } \\
\text { P. L. }\end{array}$ & $\sigma^{\prime \prime}$ & $\begin{array}{l}53 \\
55\end{array}$ & $\begin{array}{l}413 \\
692\end{array}$ & $\begin{array}{l}540 \\
613\end{array}$ \\
\hline Porphyria cutanea tarda & $\begin{array}{l}26 \\
27 \\
28 \\
29 \\
30 \\
31\end{array}$ & $\begin{array}{l}\text { H. S. } \\
\text { G. L. } \\
\text { C. L. } \\
\text { J. D. } \\
\text { M. H. D. }\end{array}$ & 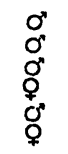 & $\begin{array}{l}55 \\
52 \\
53 \\
50 \\
39 \\
53\end{array}$ & $\begin{array}{r}767 \\
861 \\
1320 \\
2081 \\
2544 \\
5366\end{array}$ & $\begin{array}{r}655 \\
915 \\
1387 \\
2458 \\
3036 \\
5500\end{array}$ \\
\hline
\end{tabular}


two methods, the correlation is good in most cases. In all cases it was possible to distinguish unequivocally between normal and abnormal porphyrin excretion.

In ten samples from the normal group and in all samples with abnormally high porphyrin concentration the porphyrins measured by the column test were identified by comparing their behavior in thin-layer chromatography and their spectral properties to reference substances (3).

\section{Discussion}

To our knowledge, spectrophotometric assay of total porphyrins following anion exchange chromatography as described here and first developed as a qualitative porphyrin test by CASTROw and coworker (5) is the simplest and most rapid method for the quantitative detection of abnormal porphyrin excretion. The millimolar extinction coefficients of uro- and coproporphyrin in hydrochloric acid were found to be in agreement with previous measurements by other authors (cf. 6). Since the simple extinction of the Soret maximum for urine samples with normal or slightly to moderately elevated porphyrin content is not in agreement with the actual concentrations found in comparitive analyses, measurements at several wavelengths proved necessary, along with correctional factors (cf. 6). A yellow to brown coloration of the eluate can cause a relatively high background absorption, which is eliminated in calculation of the corrected extinction. The spectra were measured against distilled water (Fig. 1), since a blank value for a reagent would be too expensive for small series of tests; the use of corrected extinction values makes it superfluous anyway. A suggestion as to whether uro- or coproporphyrin predominates in a given urine sample can be obtained by exact registration of the absorption in the Soret region: A maximum at or above $404 \mathrm{~nm}$ indicates more uroporphyrin, whereas one at or below $402 \mathrm{~nm}$ indicates coproporphyrin.

If an elevated excretion of total porphyrins is apparent in column chromatography, further chromatographic and electrophoretic separation should be performed to determine which of the component porphyrins are elevated. Only then is one close to a specific diagnosis (10), which in the case of acute hepatic porphyrias or lead poisoning requires additional information on the excretion of porphyrin precursors (7). The porphyrin ion exchange test is well suited for rapid and sufficiently exact orientation concerning the severity of porphyrinuria in patients in whom a disturbance of porphyrin metabolism has been established on the basis of assays of the porphyrin precursors $(7,11)$.and analysis of the individual porphyrins $(7-10)$. We use the test for definite and rapid exclusion of elevated porphyrin excretion and for follow-up control studies.

\section{Urine of samples from patients were kindly provided}

by Dr. H. Henning and Dr. D. Look, Clinic Föhrenkamp of the BfA in Mölln (No. 18-23 and 25-31),

by Prof. Dr. G. Strohmeyer, Department of Medicine of the University Marburg (No. 10, 11, 13, 15, and 16),

by Dr. T. K. Wrth, Svendborg County Hospital, Denmark (No. 17),

by Dr. K. H. Schalder, Institute for Work and Social Medicine of the University Erlangen-Nürnberg (No. 12 and 14);

and by Dr. A. LuchmanN, Sanatorium of the LVA RheinlandPfalz for Liver and Metabolic Disorders (No. 24).

These studies were carried out with support of the Deutșche Forschungsgemeinschaft.

\section{References}

1. Doss, M. and W.-K. Philipp, this journal 7, 148 (1969). 2. Doss, M., Analytic. Biochem. (New York) 39, 7 (1971). 3. Doss, M., this journal 8, 197 (1970). - 4. Doss, M., unpublished. 5. Castrow II, F. F., J. F. Mullins and G. C. Mills, J. investigat. Dermat. 50, 340 (1968). - 6. FALK, J. E., Porphyrins and Metalloporphyrins, Elsevier, Amsterdam (1964), page 171. - 7. Doss, M. and W. Meinhof, Dtsch. med. Wschr. 96, 1006 (1971). - 8. Doss,
M., W. Meinhof, D. Look, H. Henning, P. NAwrocki, W. Dölle, G. Strohmeyer and L. Filippinr, Proc. Intern. Conf. on Porphyrin Metabolism and the Porphyrias, Cape Town (1970), S. Afr. J. Laborat. Clin. Med., in press. - 9. Doss, M., D. LooK, H. HeNNING, C. J. LÜDERS, W. DölLE and G. STROHMEYER, this journal, in press. - 10. Doss, M., Klin. Wschr. 49, 939, (1971). - 11. Doss, M. and A. Schmidr, this journal 9, 99 (1971).

Professor Dr. Manfred Doss Abteilung für Klinische Biochemie Hygiene-Institut der Universität D-355 Marburg a. d. Lahn Pilgrimstein 2 